\title{
Деструктивний поліоніхомікоз із вторинною інкарнацією нігтів: аналіз клінічних спостережень, авторські погляди на комплексне лікування
}

\begin{abstract}
Мета роботи: оптимізувати комплексне лікування та хірургічні інтервенції при хронічній оніхопатології, асоційованій з оніхомікозом та інкарнацією нігтів, включно ускладнені, комбіновані та рецидивуючі ураження.

Матеріали і методи. Здійснено ретроспективний та проспективний аналіз клінічних особливостей і результатів лікування 919 пацієнтів за 10-річний період: 503 чоловіків та 416 жінок віком 5-92 роки. Також симультанно досліджено деякі біохімічні лабораторні девіації. Видалення уражених нігтів у хворих на поліоніхомікоз здійснювали послідовними етапами на фоні системної терапії. Застосовували системну ад’ювантну пульс-терапію 400 мг ітраконазолу впродовж двох днів до первинної хірургічної корекції вторинних інкарнацій та впродовж перших трьох днів післяопераційного періоду. Санацію інших уражених нігтів з метою запобігання реінфекції мікозом проводили антимікотичним 5 \% аморолфінним лаком або 8 \% циклопіроксовмісним лаком для нігтів. Використовували клінічні, параклінічні, мікробіологічні методи, функціональну діагностику, рентгенологічні, біохімічні, морфологічні та статистичні методи.

Результати досліджень та їх обговорення. Комплексне лікування гнійної оніхеальної патології включає хірургічну резекцію або видалення нігтя, некректомію, дренування гнійних вогнищ, санацію уражень м’яких тканин, консервативне лікування мікозу та супутніх уражень. Схему комплексного лікування, що включає пульс-терапію ітраконазолом, видалення уражених нігтів, обробку нігтьового ложа полівідонйодом, використання лініменту тербінафіну та санацію інших нігтьових пластин антимікотичними лаками - циклопіроксом або аморолфіном можна використовувати для лікування тяжких випадків поліоніхомікозу. Встановлено, що піднігтьовий гіперкератоз та дерматофітома внаслідок здавлення центральної частини нігтя детермінують вторинне вростання його країв, $\chi 2=20,87, p<0,01$. Вогнища оніхолізису (оніхомадезу) та деструкції гіперкератозу, що призводять до вторинного оніхолізису, відшарування нігтьової пластини, $\chi 2=15,23, p<0,0211$, визначають та обгрунтовують доцільність малотравматичної оніхоектомії. Видалення уражених нігтів у пацієнтів з деструктивним оніхомікозом, ускладненим піднігтьовим гіперкератозом або оніхогрифозом з інкарнацією нігтя, ми здійснювали з використанням менш травматичної мобілізації нігтьової пластини через локуси оніхолізису, оніхолізовані структури за допомогою послідовного застосування стерильного леза педикюрного інструменту РЕ-60/1, із застосуванням стерильних манікюрних лез PE-10/2 та стерильного інструменту PE-30 (заокругленого пушера із зігнутим сепараційним лезом), одночасним видаленням гіперкератозу, оніхоматрикоми (дерматофітоми), змінених тканин у ділянках вростання та гіпергрануляцій, що значно зменшує травматичність процедури та детермінує зменшення післяопераційного больового синдрому $(x 2=48,32, \mathrm{p}<0,01)$, прискорення загоєння ран, поліпшення якості життя пацієнтів.
\end{abstract}

Ключові слова: оніхопатологія; деструктивний оніхомікоз; інкарнація нігтів; хірургічні інтервенції; видалення нігтьової пластини; комплексне лікування.

Постановка проблеми і аналіз останніх досліджень та публікацій. Іншими клініками [2$4,10,11]$ та нашими попередніми дослідженнями $[8,9]$ щодо сучасного стану проблеми хірургічної оніхопатології, зокрема вростання нігтя, стверджено основні клінічні варіанти, етіологічні фактори та патогенетичні ланки, базові методи комплексного лікування [3-5, 10, 11]. Наукова новизна цієї проблеми полягає в тому, що “хірургічна патологія нігтів” виділяється як новий напрямок гнійної хірургії та дерматохірургії [7-9, 13], отримано нову інформацію про різні патогенетичні механізми ізольованих та комбінованих оніхеальних уражень з виділенням конкретних клінічних та морфологічних варіантів патології нігтів, пароніхії та піднігтьових тканин [2, 6, 9, 11]. Дерматофіти, що інфікують матрикс нігтів, детермінують дистрофічні зміни, гіперкератинізацію ніг- тів, поліоніхомікоз, виникнення субунгвального гіперкератозу та дерматофітоми [2, 7, 13]; мікотичну хірургічну патологію та деформації нігтів, які ускладнені вторинним вростанням в епоніхій $[6,7]$. Ускладнений оніхомікоз та вторинна інкарнація нігтів (IH), врослий ніготь (оніхокриптоз, unguis incarnatus) характеризуються високою частотою виникнення, хронічним перебігом [1-3, 12], ускладненнями, ранніми та пізніми рецидивами $[8,9,13]$. Нівелювання проблеми в амбулаторній гнійній хірургії як простої і загальновідомої, “механістичне” лікування патології нігтьових і субунгвальних, пароніхеальних тканин, неадекватне ведення післяопераційного періоду в осіб 3 гнійно-некротичними ураженнями дистальної фаланги детермінує вторинне вростання нігтьової пластини, мікотичну реінфекцію, остеомієліт [8, 9], набуті деформації нігтя та інші різні усклад- 


\section{З ДОСВІДУ РОБОТИ}

нення [2, 6, 8, 11-13]. Найефективнішими дерматологічними методами $є$ системна антимікотична пульс-терапія [7-9, 12, 13] ітраконазолом або тербінафіном; використання антимікотичних лініментів у післяопераційному періоді, що особливо показано у комплексному лікуванні деструктивного поліоніхомікозу, включно поєднані випадки з IH [4, 8-11]. Комплексне лікування гнійної оніхеальної патології включає хірургічну резекцію або видалення нігтя, некректомію, розкриття та дренування гнійних вогнищ, санацію уражень м 'яких тканин, консервативне лікування мікозу та супутніх уражень $[8,11,12]$. Мікотично-асоційована інфекція має специфічний вплив на комплексне лікування, зокрема, на хірургічне видалення нігтів [8, 9]. Вирішено деякі суперечності та проаналізовано аспекти ефективності хірургічних методик при деструктивному та ускладненому оніхомікозі, асоційованому з вростанням нігтів та іншими комбінованими патологіями нігтів $[8,9]$. Встановлено та розроблено прогностичні критерії виникнення ранніх і пізніх ускладнень та рецидивів, схеми профілактики, комплексне лікування для поліпшення функціональних та косметичних результатів та якості життя пацієнтів [1, 3, 8, 13]. Удосконалено існуючі та оптимізовано нові способи хірургічних втручань і створено схеми комплексного лікування комбінованих процесів, включно хронічні гнійні ураження, пов’язані з мікозами [4-6, 13]. Патогенетичні фактори, що призводять до збільшення ймовірності виникнення та розвитку мікозу та оніхомікозу у хворих на цукровий діабет, включають патологію серцевосудинної та нервової систем, порушення гліколізу, що детермінує зниження енергозабезпечення клітин шкіри та зміни обміну речовин, ендотеліальну дисфункцію, сприяючи швидкому прогресуванню та хронізації [8]. За наявності інкарнації/ вростання нігтя, патологічних деформацій нігтьових пластин [4-6], гіпергрануляцій та вогнищевого піднігтьового абсцесу [8, 9] та (або) некрозу основний етап хірургічного лікування доповнюють протирецидивними компонентами [4, 5, 9].

Мета роботи: оптимізувати комплексне лікування та хірургічні інтервенції при хронічній оніхопатології, асоційованій з оніхомікозом та інкарнацією нігтів, включно ускладнені, комбіновані та рецидивуючі ураження.

Матеріали і методи. Здійснено ретроспективний та проспективний аналіз клінічних особливостей і результатів лікування 919 пацієнтів за 10-річний період: 503 чоловіків та 416 жінок віком 5-92 роки в хірургічному відділенні поліклініки 4 комунальної клінічної лікарні, хірургічних відділеннях 2 та 5 міських поліклінік і міської дерматологічної лікарні м. Львова. Згідно з проектом і дизайном дослідження застосовували деякі клінічні та параклінічні, мікробіологічні методи, функціональну діагностику, рентгенологічні, біохімічні, морфологічні та статистичні методи. У 186 пацієнтів пізні рецидиви оніхокриптозу були підтверджені після попередніх операцій в інших клініках. Консервативне лікування рекомендувалося лише на ранніх стадіях вростання. Застосовували системну ад 'ювантну пульс-терапію 400 мг ітраконазолу [8, 12, 13] впродовж двох днів до початкового хірургічного лікування вторинної мікотичної IH та впродовж перших трьох днів післяопераційного періоду. Також паралельно з антимікотичною терапією та корекцією коморбідної патології були проведені такі процедури: висічення патологічних епоніхеальних тканин, гіпергрануляцій та некрозів, резекція IH або видалення нігтьової пластинки 3 частковою крайовою матриксектомією в ділянці вростання. Санацію інших уражених нігтів з метою запобігання реінфекції мікозом проводили антимікотичними лаками для нігтів 3 5 \% аморолфіном [1, 12] або 8 \% циклопіроксом [3]. Видалення трихофітно уражених нігтів (через оніхолізовані структури) на окремих етапах поєднували з терапією ітраконазолом [8, 12]. Проспективні спостереження, проліковані та прооперовані за авторськими способами, становили основну, ретроспективні випадки - групу порівняння (контрольну групу). Аналіз основного розподілу за віком і статтю пацієнтів в основній групі та групи порівняння (контрольної групи) не виявив суттєвої різниці ( $>0,05)$, тобто групи були нозологічно, клінічно та гендерно зіставні. Проведено дослідження морфогенезу оніходеструктивного та інкарнаційного аспектів мікотичних уражень. Ретроспективним матеріалом було 295 спостережень неускладненої деструктивної хірургічної патології нігтів, пацієнти віком від 11 до 85 років: 177 чоловіків та 118 жінок. Пацієнти молодого віку становили 26,44 \%, середнього - 32,20 \%, а люди похилого віку - 41,36 \% ретроспективної підгрупи. Проспективним матеріалом були 624 випадки деструкції нігтів: 326 чоловіків та 298 жінок, вік оперованих пацієнтів - від 5 до 92 років. Також досліджено особливості лікування, деякі показники ліпідного обміну хворих на цукровий діабет, метаболічний синдром, що (як коморбідна та фонова патологія) сприяв деструктивному оніхомікозу та вторинним IH [6, 8, 9, 13]. Видалення уражених нігтів у хворих на поліоніхомікоз здійснювали послідовними етапами на фоні (під при- 
криттям) системної “пульс” терапії ітраконазолом [8]. Застосовували системну ад 'ювантну пульстерапію 400 мг ітраконазолу впродовж двох днів до початкового хірургічного лікування вторинної мікотичної IH та впродовж перших трьох днів післяопераційного періоду. Також з антимікотичною терапією та корекцією коморбідної патології були проведені такі процедури: висічення патологічних епоніхеальних тканин, гіпергрануляцій та некрозів, резекція IH або видалення нігтьової пластинки 3 частковою крайовою матриксектомією в ділянці вростання [4, 5, 8-11]. Застосовували неінвазивні методи видалення нігтів $[8,11]$ та крайової резекції нігтів у 24,7 \% пацієнтів основної групи та у хворих на цукровий діабет. Санацію інших уражених нігтів із метою запобігання реінфекції мікозом проводили антимікотичними лаками для нігтів 35 \% аморолфіном або 8 \% циклопіроксом. Видалення інших трихофітозних нігтів (через оніхолізовані структури) на окремих етапах поєднували 3 терапією ітраконазолом. Модифікації різних показників до- та після лікування визначали за допомогою тесту Вілкоксона. Різницю в досліджуваних параметрах враховували при $\mathrm{p} \leq 0,05$. Застосовано деякі стандартні методи статистичного аналізу з довірювальним інтервалом 95 \%, t-критерій Стьюдента, методи Пірсона та Спірменса, X2 (з аналізом ступеня впливу етіологічних факторів, морфогенетичних механізмів, кореляції між нозологічними формами, морфологічними прояви та ефективністю комплексного лікування); також використовували регресійну модель ANOVA. Аналіз обгрунтовує доцільність встановлення прогностичних взаємозв’язків між клінічними варіантами хронічних гнійно-некротичних інфекцій, комбінованими ураженнями та коморбідною патологією.

Результати досліджень та їх обговорення. Було встановлено, що молоді люди в основному страждають від неускладненого оніхокриптозу, x2=24,12, p=0,028; літні пацієнти - від мікотично-асоційованої оніходеструкції з вираженою загальною гіпертрофією нігтьових пластин [2, 6-8], виникненням піднігтьового/субунгвального гіперкератозу [6, 8], оніхогрифозу [6], піднігтьових дерматофітом $[2,7]$, вторинної IH, інших вторинних гнійних оніхеальних субунгвальних та пароніхеальних уражень ( $\mathrm{p}=0,012)$, що може бути у деяких пацієнтів причиною розвитку мікотичного асоційованого остеомієліту дистальної фаланги [8]. Ці варіанти вторинного руйнування нігтів при поліоніхомікозі характерні для середнього віку та пацієнтів літнього віку (ступінь впливу х2=24,12, рівень значимості $\mathrm{p}=0,028)$. Пік захворюваності на неускладнені випадки (включно оніхокриптоз) стверджено у пацієнтів, віком 30-40 років, посереднє зростання частоти ускладнених клінічних спостережень - у пацієнтів 30-40 років та 6070 років, деяких комбінованих уражень - у пацієнтів 40-50-річного віку. Найбільше вираженими були оніхеальні зміни при ускладненому оніхомікозі ( 2 2=20,87, p<0,01) та тотальній мікотичній деструкції нігтів, діагностовано випадки вторинної IH, x2=17,35, p=0,022, коефіцієнт Спірмена ( $\rho)$ у дослідних групах становив 0,552-0,617, що детермінувалося деформаціями нігтів і супроводжувалося вростаннями нігтів в епоніхеальні тканини, $x^{2}=5,11-36,22, \mathrm{p}<0,05$.

Аналіз субунгвальних зішкрібків в осіб з оніхомікотичними ураженнями та вторинною IH дозволив констатувати переважання дерматофітів (червоної трихофітії), $\chi 2=35,43, \mathrm{p}<0,01$. У третини пацієнтів виявлено асоціації мікотичних збудників та бактеріальної флори, які призводили до виникнення гострих гнійних процесів. Приєднання кандидозної, бактеріальної або змішаної суперінфекції у 21,08 \% пацієнтів детермінувало формування безсимптомного піднігтьового панарицію змішаної етіології (з множинними гнійними локусами, схожими на “бджолині стільники”), що є безпосередньою причиною тяжких, у тому числі інвалідизуючих ускладнень, включно хронічний мікотично асоційований остеомієліт дистальної фаланги. Ретро- та проспективно вивчено 414 випадків інкарнацій, включно оніхокриптоз як неускладнений варіант вростання нігтів [4, 5, 9]. Стверджено, що патогенез IH досить складний, може одночасно включати 1-4 “порочних кіл”, $\chi 2=27,41, \mathrm{p}<0,01$, коефіцієнт Спірмена ( $\rho)$ у дослідних групах 0,5520,617 [9]. Діагностували клінічно маніфестуючі та латентні випадки вростання нігтів, іншу хронічну фонову та супутню патологію нігтів, пов’язану 3 онохокриптозом [3-7, 13]. Доведено, що ускладнені та поєднані випадки оніхокриптозу та мікотичних уражень становили майже половину - 196 (44,95 \%) усіх спостережень; випадки неускладненої IH - 167 (38,3 \%) випадків вибірки. Вік пацієнтів із ускладненою хірургічною оніхопатологією, асоційованою з врослим нігтем, становить: 51,8 \% - пацієнти 20-40-річного віку, таке ураження підтверджено у 91 пацієнта віком 20-30 років (20,9 \% від загальної вибірки), а в інших 97 (22,25 \%) від 30-40-річного віку. Пацієнти віком 40-50 років, включно 75 спостережень (17,2%); 24 (4,5%) випадки інкарнаційної хірургічної оніхопатології - це особи віком 50-60 років. У хворих на поліоніхомікоз, асоційований з вторинною IH, у біль- 


\section{З ДОСВІДУ РОБОТИ}

шості спостережень діагностовано тяжку грибкову інфекцію з гіпертрофією нігтів, утворенням піднігтьового гіперкератозу або оніхогрифозу, $\chi 2=20,41$, $\mathrm{p}<0,01$ та оніхоматрикоми (дерматофітоми, трихофітоми), виникали труднощі для виконання хірургічної інтервенції. Ускладнені інкарнації у пацієнтів інших вікових груп були порівняно рідкісними. Пік спостережень за неускладненим оніхокриптозом припадав на групи пацієнтів 20-40-річного віку, пік випадків деструктивних трихофітних уражень із IH спостерігався у інших пацієнтів 40-50-річного та 50-60-річного віку. Найчастіше уражався галюкс лівої стопи - у 48,85 \%, правої у 33,26 \%, наявність ІН обох галюксів виявлено у 17,89 \% пацієнтів.

Проаналізовано результати лікування 108 випадків (на тлі метаболічного синдрому та цукрового діабету) деструктивного полініхомікозу, ускладненого гнійними захворюваннями нігтя та епоніхеальних тканин. У хворих на оніхомікоз, особливо при множинних ураженнях, наявності піднігтьового гіперкератозу або поліоніхогрифозу, фоново відзначалися погіршення мікроциркуляції. У пацієнтів основної групи на периферичних реовазограмах виявлено підвищений тонус дрібних судин. Реографічні криві мали спастичний вигляд у 48,7 \% субвибірки, у 32,1 \% - гіпотонічні та дистонічні у 19,2 \% спостережень. Переважали спастичні типи реографічних кривих ( $\mathrm{y}=30,6, \mathrm{P}<0,01)$. Індекс відкритих капілярів був знижений до 31 \%. Існувала позитивна кореляція між рівнем загального холестерину та лептину ( $r=0,38 ; \mathrm{p}<0,01)$. Підвищений $\mathrm{pi}-$ вень загального холестерину понад 5,2 ммоль/л спостерігався у пацієнтів основної групи $(6,31 \pm 0,09)$ ммоль/л, а у хворих групи контролю - $(6,33 \pm 0,11)$ ммоль/л. Рівень холестерину ЛПНЩ був більше 3,0 ммоль/л у пацієнтів основної групи - $(3,34 \pm 0,2)$ ммоль/л, у хворих $з$ контрольної групи - $(3,32 \pm 0,15)$ ммоль/л, коефіцієнт Спірмена ( $\rho)$ у досліджуваних групах 0,513-0,609. Концентрація холестерину ЛПВЩ в осіб основної групи становила $(1,36 \pm 0,05)$ ммоль/л, у пацієнтів контрольної групи - $(1,12 \pm 0,03)$ ммоль/л. Середній вміст оксиду азоту у хворих основної групи, яким проводили стандартну оніхектомію, був незначно вищим - $(15,46 \pm 0,35)$ мкмоль/л, $\mathrm{p}<0,05$ ( $x 2=8,11$, рівень значимості, $\mathrm{p}=0,032)$, порівняно 3 випадками, коли застосовували малотравматичне видалення мікотичних змін нігтів; цей параметр також дещо відрізнявся в осіб із неускладненим оніхомікозом, відповідно становив $(12,32 \pm 0,23)$ мкмоль/л та $(11,62 \pm 1,51)$ мкмоль/л, p> 0,05. Встановлено, що частота мікозів і оніхо- мікозів стоп у хворих на цукровий діабет перевищує цей показник для пацієнтів загальної популяції, $\chi 2=13,69$, що також підтверджено результатами двофакторного дисперсійного аналізу, p<0,05. Зміни біохімічних показників у хворих на метаболічний синдром та цукровий діабет були пов'язані з ліпідним обміном; підвищений рівень холестерину більше 5,18 ммоль/л; холестерин ЛПВЩ $(1,12 \pm 0,06)$ ммоль/л, $\mathbf{p}<0,05$. У цих пацієнтів була наявна інсулінорезистентність [6-9]: НОМАіндекс інсулінорезистентності $(8,11 \pm 1,1, \Gamma<0,01)$ та глікований гемоглобін $(11,1 \pm 1,5 \%, \mathrm{R}<0,05)$, зниження функції $\beta$-клітин та збільшення індексу HOMA-IR, кореляція рівня глюкози з інсуліном ( $\mathrm{r}=0,52 ; \mathrm{p}<0,01), 3$ індексом HOMА ( $\mathrm{r}=0$, $69 ; \mathrm{p}<0,01), 3$ глікованим гемоглобіном $(\mathrm{r}=0,76$; $\mathrm{p}<0,01)$; рівня інсуліну з індексом НОМА ( $\mathrm{r}=0,74$; $\mathrm{p}<0,01)$ та глікованим гемоглобіном ( $\mathrm{r}=0,65$; $\mathrm{p}<0,01)$; індексу НОМА з глікованим гемоглобіном $(\mathrm{r}=0,69 ; \mathrm{p}<0,01)$. У хворих на цукровий діабет виявлено кореляцію між інсулінорезистентністю, рівнем глікованого гемоглобіну та частотою виникнення ускладнень оніхомікозу, вторинної інкарнації та деформації нігтів, $\chi 2=28,21, \mathrm{p}<0,05$.

Встановлено, що піднігтьовий гіперкератоз та дерматофітома внаслідок здавлення центральної частини нігтя детермінують вторинне вростання його країв, $x 2=20,87, p<0,01$. Аналіз субунгвальних зішкрібків в осіб з оніхомікотичними ураженнями та вторинною IН дозволив констатувати переважання дерматофітів (червоної трихофітії), $\mathrm{x} 2=35,43, \mathrm{p}<0,01$, у третини пацієнтів виявлено асоціації мікотичних збудників та бактеріальної флори. Приєднання кандидозної, бактеріальної або змішаної суперінфекції у 21,08 \% пацієнтів детермінує формування безсимптомного піднігтьового панарицію змішаної етіології (з множинними гнійними локусами, які макроскопічно схожі на “бджолині стільники”) $[2,6-8,13]$, що $є$ безпосередньою причиною тяжких, у тому числі інвалідизуючих ускладнень, включно хронічний мікотично асоційований остеомієліт дистальної фаланги. Найбільше вираженими були оніхеальні зміни при ускладненому оніхомікозі [2-4, 6-9] $(x 2=20,87, p<0,01)$ та тотальній мікотичній деструкції нігтів (рис. 1) [2, 6, 7, 13], діагностовано випадки вторинної IH, $\chi 2=17,35, \mathrm{p}=0,022$, коефіцієнт Спірмена ( $\rho)$ у дослідних групах становив 0,552-0,617, що детермінувалося деформаціями нігтів і супроводжувалося вростаннями нігтів в епоніхеальні тканини, $\chi 2=5,11-36,22, p<0,05$. Асоціації мікотичних збудників та бактеріальної флори у $31 \%$ випадків, $\chi 2=20,87, \mathrm{p}<0,01$ призводили до виникнення гострих гнійних процесів. Збіль- 
шення парціального відсотка рецидивів інкарнації свідчить про необхідність антирецидивних одномоментних інтраопераційних технічних заходів, x2=31,23, p<0,01, зокрема - крайової парціальної прецизійної матриксектомії в ділянці вростання [4, 5, 9-11], як найбільш оптимального антирецидивного компоненту х2=18,21, p<0,01 (відповідно стверджено зменшення частоти повторних IH до 1-3 \% ранніх, 3,25 \% та 6,42 \% пізніх рецидивів вростання; $x 2=28,17, \mathrm{p}<0,01)$.

Хірургічні інтервенції проводили з урахуванням патологічних змін, $\chi 2=21,23, p=0,012$, відповідно до наших попередніх рекомендацій поєднання хірургічних втручань та консервативної терапії, x2=28,17, p<0,01. Була використана блокоподібна епоніхектомія як авторська методика візуалізації краю нігтя для лікування ускладненого та комбінованого врослого нігтя з видаленням “еn block” епоніхеальної тканини 3 мікроабсцесами, некрозами та гіпергрануляціями. Хірургічне ви- далення уражених мікозом нігтів проводили через ділянки розшарування гіперкератозу нігтьового ложа та оніхолізовані структури з одночасним видаленням дерматофітоми [2, 6-8], субунгвального гіперкератозу [6, 7], ділянок вростання та розшарування нігтя з гіпергрануляціями $[4,6,8,9]$. Вогнища оніхолізису (оніхомадезу) та деструкції гіперкератозу, що призводять до вторинного оніхолізису, відшарування нігтьової пластини та вторинної IH, $\chi 2=15,23, \mathrm{p}<0,0211$ [8, 9], визначають та обгрунтовують доцільність малотравматичної оніхоектомії з одноетапним послідовним видаленням дерматофітоми та крайовою резекцією росткової зони з епоніхеальними тканинами [8]. Видалення уражених нігтів у пацієнтів з деструктивним оніхомікозом, ускладненим піднігтьовим гіперкератозом або оніхогрифозом з IH, ми здійснювали з використанням менш травматичної мобілізації нігтьової пластини через локус піднігтьового гіперкератозу, оніхолізовані структури за до-
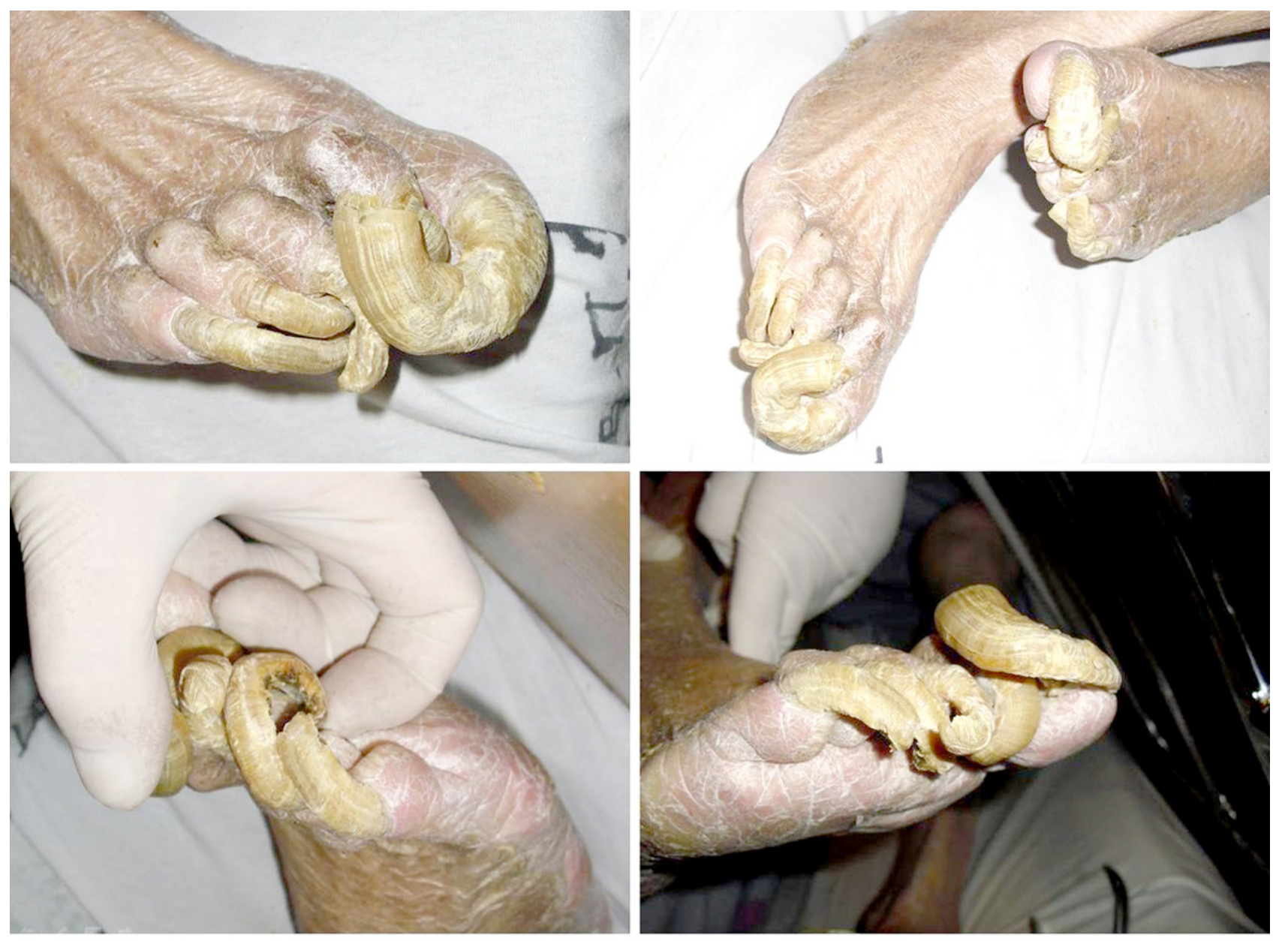

Рис. 1. Випадок деструктивного поліоніхомікозу з множинними вторинними інкарнаціями: трихофітійний гігантський оніхогрифоз нігтьових пластин у хворого М., 83 роки, відділення паліативної допомоги КНП “МКЛ” м. Львова, 15 травня 2020 року. 
помогою послідовного застосування стерильного леза педикюрного інструмента PE-60/1, із застосуванням стерильних манікюрних лез PE-10/2 та стерильного інструменту PE-30 (заокругленого пушера з зігнутим сепараційним лезом), одночасним видаленням гіперкератозу, оніхоматрикоми (дерматофітоми) [2, 6, 7], змінених тканин у ділянках вростання (парціальною маргінальною матриксектомією механічним висіченням та діатермокоагуляцією) [5] та гіпергрануляцій [5, 8-10]. Розсікали та відсепаровували вростаючий край нігтя від ложа та матриксу до візуально здорових тканин ковзними рухами із застосуванням стерильних манікюрних пушерів РE-10/2 (заокруглений з лопаткою - распатором) та РE-30 та виконували часткову резекцію або видалення нігтів із подальшою санацією ділянки резекції за допомогою стерильних педикюрних лез з операційною абразивною пилкою РЕ-60 (РЕ-60/2 - кутовим рашпилем та рашпилем із вигнутим кінцем). Виконували часткову крайову матриксектомію з поздовжнім механічним висіченням та коагуляцією нігтьового матриксу в ділянці вростання. Санацію епоніхеальних “каналів” проводили ложкою Фолькмана та стерильним пушером [8]. Рану промивали 3 \% розчином перекису водню та розчином полівідон-йоду та здійснювали девульсію залишених епоніхеальних тканин із гемостатичною тампонадою під візуальним контролем. Застосована інтра- та післяопераційна профілактика мікотичних повторних та змішаних інфекцій за допомогою оптимізованої схеми: пульстерапії 400 мг ітраконазолу в день, місцевої антимікотичної терапії (лініменти полівідонйоду, тербінафіну), нігтьового антимікотичного лаку (циклопірокс або аморолфін), які при комплексному застосуванні підвищують ймовірність клінічного та мікологічного одужання. Максимальна частота рецидивів поліоніхомікозу спостерігалася впродовж 12-15 місяців, $\chi 2=25,52, p=0,018$, в разі системної терапії - на третій рік після лікування, $\chi 2=13,47$, $\mathrm{p}=0,023$, в таких випадках нерідко виникали показання до повторних втручань, $\rho=0,511-0,791$. Мобілізація нігтів через оніхолізовані структури значно зменшує травматичність процедури та детермінує зменшення післяопераційного больового синдрому ( $\chi 2=48,32, \mathrm{p}<0,01)$, поліпшення якості життя пацієнтів.

У хворих на цукровий діабет при виконанні “класичноі” оніхектомії цей термін становив 24-30 днів відповідно (середня тривалість загоєння 26 днів), у контрольній групі 14-22 дні (середня тривалість загоєння 18 днів). Таким чином у хворих на цукровий діабет 2 типу, яким здійснено менш травматичне видалення мікотичних нігтів через оніхолізовані структури, терміни загоєння нігтьових лож були меншими і наближалися до термінів загоєння у пацієнтів контрольної групи (з нормальною глікемією) з деструктивним поліоніхомікозом, оніхогрифозом і вторинним НI, r=0,38; p<0,01. На 14-й день індекс Попової в основній групі становив 18,97 \% (від 15,3 до 21,8 \%), у контрольній групі - $(12,1 \pm 2,85)$ \%, (х2=32,14, $\mathrm{p}<0,01)$, що вказує на суттєві переваги малотравматичної оніхектомії порівняно з класичними методами. У пацієнтів, які отримували лише пероральний ітраконазол, клінічна ремісія оніхомікозу через 1,5 року після початку лікування становила 80,26 \%, тоді як у групі, яка отримувала ітраконазол та місцево лінімент тербінафіну, становила 82,69\%.

Висновки. Доведено наявність залежності між даними анамнезу, а також клінічними проявами ( $\mathrm{y}=16,9 \mathrm{p}<0,05, \mathrm{r}=0,7)$, поширеністю уражень мікозом шкіри та нігтьових пластин з артеріальною патологією ( $\mathrm{y}=15,5, \mathrm{P}<0,05, \mathrm{r}=+0,8)$, що також корелює з віком пацієнтів. Вогнища оніхолізису (оніхомадезу) та деструкції гіперкератозу, що призводять до вторинного оніхолізису, відшарування нігтьової пластини та вторинної IH ( 2 =15,23, p<0,0211), визначають та обгрунтовують доцільність малотравматичної оніхоектомії з одноетапним послідовним видаленням дерматофітоми і крайовою резекцією росткової зони зі зміненими епоніхеальними тканинами. Методи хірургічного лікування піднігтьового гіперкератозу та оніхогрифозу з рецидивуючою IH або без вростання нами вдосконалено з урахуванням пато- та морфогенезу деструктивного ускладненого поліоніхомікозу, - елімінацією змінених нігтьових пластин через ділянки розшарування гіперкератозу нігтьового ложа та оніхолізовані структури з одночасним видаленням дерматофітоми, субунгвального гіперкератозу, ділянок вростання та розшарування нігтя з гіпергрануляціями, що детермінує зменшення післяопераційного больового синдрому ( $x 2=48,32, \mathrm{p}<0,01$, поліпшення якості життя пацієнтів. Схему комплексного лікування, що включає пульс-терапію ітраконазолом, видалення уражених нігтів, обробку нігтьового ложа полівідонйодом, використання лініменту тербінафіну та санацію інших нігтьових пластин антимікотичними лаками - циклопіроксом або аморолфіном можна використовувати для лікування тяжких випадків поліоніхомікозу. 


\section{З ДОСВІДУ РОБОТИ}

\section{СПИСОК ЛІТЕРАТУРИ}

1. Ghannoum M. Erratum to: amorolfine $5 \%$ nail lacquer exhibits potent antifungal activity compared to three acid-based devices indicated for the treatment of onychomycosis: an in vitro nail penetration assay / M. Ghannoum, K. Sevin, M. Sarkany // Dermatol. Ther. (Heidelb). - 2016. - Vol. 6 (3). - P. 451.

2. Goettmann S. Onychomatricoma with pterygium aspect: unusual clinical presentation / S. Goettmann, I. Zaraa, I. Moulonguet // Acta Derm. Venereol. - 2006. - Vol. 86 (4). - P. 369-370.

3. Gupta A. K. Ciclopirox nail lacquer topical $8 \%$ solution in the treatment of toenail onychomycosis / A. K. Gupta // J. Amer. Acad. Dermatol. - 2001. - Vol. 43 (1). - P. 81-95.

4. Kim J. Y. Treatment of symptomatic incurved toenail with a new device / J. Y. Kim, J. S. Park // Foot Ankle Int. - 2009. Vol. 30 (1). - P. 1083-1087.

5. Kim M. partial removal of nail matrix in the treatment of ingrown nails: prospective randomized control study between curettage and electrocauterization / M. Kim, I.-G. Song, H. J. Kim // Int. J. Low Extrem. Wounds. - 2015. - Vol. 14 (2). - P. 192-195. 6. Morphologic study of normal, ingrown, and pincer nails / M. Kosaka, H. Kusuhara, Y. Mochizuki [et al.] // Dermatol. Surg. - 2010. - Vol. 36 (1). - P. 31-38.

7. Dermatophytoma: An under-recognized condition / C. Leeyaphan, S. Bunyaratavej, N. Prasertworanun [et al.] // Indian. J. Der-

\section{REFERENCES}

1. Ghannoum, M., Sevin, K., \& Sarkany, M. (2016). Erratum to: amorolfine $5 \%$ nail lacquer exhibits potent antifungal activity compared to three acid-based devices indicated for the treatment of onychomycosis: an in vitro nail penetration assay. Dermatol. Ther. (Heidelb), 6 (3), 451.

2. Goettmann, S., Zaraa, I., \& Moulonguet, I. (2006). Onychomatricoma with pterygium aspect: unusual clinical presentation. Acta Derm. Venereol., 86 (4), 369-370.

3. Gupta, A. K. (2001). Ciclopirox nail lacquer topical $8 \%$ solution in the treatment of toenail onychomycosis. J. Amer. Acad. Dermatol., 43 (1), 81-95.

4. Kim, J.Y., \& Park, J.S. (2009). Treatment of symptomatic incurved toenail with a new device. Foot Ankle Int., 30 (1), 10831087.

5. Kim, M., Song, I.-G., \& Kim, H.J. (2015). Partial removal of nail matrix in the treatment of ingrown nails: prospective randomized control study between curettage and electrocauterization. Int. J. Low Extrem. Wounds, 14 (2), 192-195.

6. Kosaka, M., Kusuhara, H., Mochizuki, Y., Mori, H., \& Isogai, N. (2010). Morphologic study of normal, ingrown, and pincer nails. Dermatol. Surg., 36 (1), 31-38.

7. Leeyaphan, C., Bunyaratavej, S., Prasertworanun, N., Muanprasart, C., Matthapan, L., \& Rujitharanawong, C. (2016). Der- matol. Venereol. Leprol. - 2016. - Vol. 82 (2). - P. 188-189. 8. Vergun A. R. Destructive complicated onychomycosis with nail incarnation: case series, complex surgical treatment / A. R. Vergun // Вісник наукових досліджень. - 2017. - № 4. - C. 56-60.

9. Vergun A. R. Ingrown nail, optimal clinical and morphological classifications: author 's views (own modification) and discussion / A. R. Vergun // Шпитальна хірургія. Журнал імені Л. Я. Ковальчука. - 2017. - № 4. - С. 46-50.

10. Acar E. Winograd method versus winograd method with electrocoagulation in the treatment of ingrown toenails / E. Acar // J. Foot Ankle Surg. - 2017. - Vol. 56 (3). - P. 474-477.

11. Zavala Aguilar K. Management of onychocryptosis in primary care: A clinical case / K. Zavala Aguilar, F. Gutiérrez Pineda, E. Bozalongo de Aragón // Semergen. - 2013. - Vol. 39 (6). - P. 38-40.

12. Lecha M. Amorolfine and itraconazole combination for severe toenail onychomycosis; results of an open randomized trial in Spain / M. Lecha // Br. J. Dermatol. - 2001. - Vol. 145, Suppl. 60. - P. 21-26.

13. Zeichner J. A. Onychomycosis to fungal superinfection: prevention strategies and considerations / J. A. Zeichner // J. Drugs Dermatol. - 2015. - Vol. 14 (10). - P. 32-34.

matophytoma: An under-recognized condition. Indian. J. Dermatol. Venereol. Leprol., 82 (2), 188-189.

8. Vergun, A.R. (2017). Destructive complicated onychomycosis with nail incarnation: case series, complex surgical treatment. Visnyk naukovykh doslidzhen - Bulletin of Scientific Research, 4, 56-60.

9. Vergun, A.R. (2017). Ingrown nail, optimal clinical and morphological classifications: author 's views (own modification) and discussion. Shpytalna khirurhia. Zhurnal imeni L.Ya. Kovalchuka - Hospital Surgery. Journal Named by L.Ya. Kovalchuk, 4, 46-50.

10. Acar, E. (2017). Winograd method versus winograd method with electrocoagulation in the treatment of ingrown toenails. $J$. Foot Ankle Surg., 56 (3), 474-477.

11. Zavala Aguilar, K., Gutiérrez Pineda, F., \& Bozalongo de Aragón, E. (2013). Management of onychocryptosis in primary care: A clinical case. Semergen., 39 (6), 38-40.

12. Lecha, M. (2001). Amorolfine and itraconazole combination for severe toenail onychomycosis; results of an open randomized trial in Spain. Br. J. Dermatol., 145, 60, 21-26.

13. Zeichner, J.A. (2015). Onychomycosis to fungal superinfection: prevention strategies and considerations. J. Drugs Dermatol., 14 (10), 32-34. 


\title{
DESTRUCTIVE POLYONYCHOMYCOSIS WITH SECONDARY NAILS INCARNATION: ANALYSIS OF CLINICAL OBSERVATIONS, AUTHOR 'S VIEWS OF COMPLEX TREATMENT
}

\begin{abstract}
The aim of the work: optimization of the complex treatment and surgical intervention for chronic onychopathology associated with onychomycosis and nail incarnation, including complicated, combined and recurrent lesions.

Materials and Methods. A retrospective and prospective analysis of clinical cases and treatment outcomes of 919 patients over a 10 year period: 503 men and 416 women aged 5-92 years were performed. Some biochemical laboratory deviations also simultaneously were studied. Removal of the affected nails in patients with polyonychomycosis was carried out simultaneously with systemic therapy. Systemic $400 \mathrm{mg}$ itraconazole adjuvant pulse therapy used for two days before the primary surgical correction of deformations and incarnations and for the first three days of the postoperative period. Sanation of other affected nails to prevent mycosis reinfection was performed with antifungal $5 \%$ amorolfine or $8 \%$ cyclopyrox nail lacquer. Clinical, paraclinical, microbiological methods, functional diagnostics, radiological, biochemical, morphological methods and statistical analysis were used.

Results and Discussion. Complex treatment of purulent onycheal pathology includes surgical resection or the nail removal, necrectomy and drainage of purulent foci, sanation of soft tissue lesions, conservative treatment of mycosis and comorbide lesions. The complex treatment scheme, which includes pulse therapy with itraconazole, removal of affected nails, treatment of the nail matrix with polyvidone iodine, use of terbinafine liniment and sanation of other nail plates with antifungal lacquer - cyclopirox or amorolfine can be used to treat of difficult polyomycosis cases. It was found that subungual hyperkeratosis and dermatophytoma due to compression of the central part of the nail determine the secondary ingrowth of the nail edges, $x 2=20.87, p<0.01$. The foci of onycholysis (onychomadesis) and destruction of hyperkeratosis, leading to secondary onycholysis and detachment of the nail plate, $x 2=15.23$, $p<0.0211$, determines some methods of minimally invasive onychectomy. Removal of affected nails in patients with destructive onychomycosis complicated by subungual hyperkeratosis or onychogryphosis with nail incarnation is carried out using less traumatic mobilization of the nail plate through the loci of onychomadesis, onycholysis structures with dissection of tissues with sterile PE-10/2 blades and sterile PE-30 instrument (rounded pusher with curved separation blade), simultaneous removal of hyperkeratosis, onychomatricoma (dermatophytoma), necrotical tissues in areas of ingrowth and hypergranulation, which significantly reduces the trauma of the procedure and determines the reduction of postoperative pain $\left(x^{2}=48.32, \mathrm{p}<0.01\right)$, accelerating wound healing, improving the quality of life.
\end{abstract}

Key words: onychopathology; destructive onychomycosis; nail incarnation; surgical interventions; nail plate removal; complex treatment.

\author{
А. Р. ВЕРГУН, М. Р. КРАСНЫЙ, З. М. КИТ, О. М. ВЕРГУН
}

Львовский национальный медицинский университет имени Данила Галицкого

\section{ДЕСТРУКТИВНЫЙ ПОЛИОНИХОМИКОЗ С ВТОРИЧНОЙ ИНКАРНАЦИЕЙ НОГТЕЙ: АНАЛИЗ К.ЛИНИЧЕСКИХ НАБ.ЛЮДЕНИЙ, АВТОРСКИЕ ВЗГЛЯДЫ НА КОМП.ЛЕКСНОЕ ЛЕЧЕНИЕ}

Цель работы: оптимизировать комплексное лечение и хирургические интервенции при хронической онихопатологии, ассоциированной с онихомикозом и инкарнацией ногтей, включая осложненные, комбинированные и рецидивирующие поражения. Материалы и методы. Ретроспективно и проспективно проанализировано клинические особенности и результаты лечения 919 пациентов за 10-летний период: 503 мужчин и 416 женщин в возрасте 5-92 лет. Также симультанно исследованы некоторые биохимические лабораторные девиации. Удаление пораженных ногтей у больных полионихомикозом осуществляли последовательными этапами на фоне системной терапии. Применяли системную адъювантную пульс-терапию 400 мг итраконазола в течение двух дней до первичной хирургической коррекции вторичных инкарнаций и в течение первых трех дней послеоперационного периода. Санацию других пораженных ногтей с целью предотвращения реинфекции микозом проводили антимикотическим 5 \% аморолфинным лаком или 8 \% циклопирокссодержащим лаком для ногтей. Использовали клинические, параклинические, микробиологические методы, функциональную диагностику, рентгенологические, биохимические, морфологические и статистические методы.

Результаты исследований и их обсуждение. Комплексное лечение гнойной онихеальной патологии включает хирургическую резекцию или удаление ногтя, некрэктомию, дренирование гнойных очагов, санацию поражений мягких тканей, консервативное лечение микоза и сопутствующих поражений. Схему комплексного лечения, включающую пульс-терапию итраконазолом, удаление пораженных ногтей, обработку ногтевого ложа поливидонйодом, использование линимента тербинафина и санацию других ногтевых пластин противогрибковыми лаками - циклопироксом или аморолфином можно использовать для лечения тяжелых случаев полионихомикоза. Констатировано, что подногтевой гиперкератоз и дерматофитома вследствии сдавления центральной части ногтя детерминируют вторичное врастание его краев, $\chi 2=20,87, \mathrm{p}<0,01$. Очаги онихолизиса (онихомадеза) и деструкции гиперкератоза, приводящие к вторичному онихолизису, отслоение ногтевой пластины, $x 2=15,23, \mathrm{p}<0,0211$, определяют и обосновывают целесообразность малотравматичной онихоэктомии. Удаление пораженных ногтей у пациентов с деструктивным онихомикозом, осложненным подногтевым гиперкератозом или онихогрифозом с инкарнацией ногтя нами осуществляется с использованием менее травматичной мобилизации ногтевой пластины через локусы онихолизиса, онихолизированные структуры с помощью последовательного применения стерильного лезвия педикюрного инструмента РЕ-60/1, с применением стерильных маникюрных лезвий РE-10/2 и стерильного инструмента РЕ-30 (полукруглого пушера с изогнутым сепарационным лезвием), одновременным удалением гиперкератоза, онихоматрикомы (дерматофитомы), измененных тканей в участках врастания и гипергрануляций, что значительно уменьшает травматичность процедуры и детерминирует уменьшение послеоперационного болевого синдрома $\left(\mathrm{x}^{2}=48,32, \mathrm{p}<0,01\right)$, ускорение заживления ран, улучшения качества жизни пациентов.

Ключевые слова: онихопатология; деструктивный онихомикоз; инкарнация ногтей; хирургические интервенции; удаление ногтевой пластины; комплексное лечение. 